\title{
EFEKTIVITAS PROGRAM CCDP-IFADTERHADAP MUTU MIKROBIOLOGI DAN ORGANOLEPTIK IKAN ASAP DI KOTA TERNATE (STUDI KASUS KELOMPOK INDUSTRI PENGASAPAN KELURAHAN FAUDU KECAMATAN PULAU HIRI)
}

\author{
Ibnu Wahab Laitupa* \\ Staf Pengajar FAPERTA UMMU-Ternate, Email: ibnulaitupa3@gmail.com
}

\begin{abstract}
ABSTRAK
Sumberdaya ikan yang begitu besar tak berbanding lurus dengan realita masyarakat pesisir Kota Ternate yang masih di bawah garis kemiskinan. Program Coastal Community Development Project - International Fund for Agricultural Development (CCDP-IFAD) hadir sebagai upaya pemberdayaan ekonomi, salah satunya upaya pengembangan industri pengasapan ikan. Penelitian ini dimaksudkan sebagai penelitian evaluatif dan bertujuan menganalisis efektivitas program CCDP-IFAD terhadap mutu mikrobiologi dan organoleptik ikan asap dari nelayan penerima program serta pendapatan nelayan pengasapan ikan di Kelurahan Faudu Kota Ternate. Metode yang digunakan adalah kualitatif dan kuantitatif. Analisis inferensi sampel berpasangan untuk membandingkan nilai pendapatan, dan analisis ragam untuk membandingkan mutu organoleptik. Hasil penelitian menunjukkan bahwa (1) Uji inferensi sampel berkesimpulan bahwa adanya program tidak berpengaruh signifikan pada kenaikan pendapatan (2) $U j i$ organoleptik pada parameter kenampakan, rasa, aroma dan tekstur berdasarkan analisis ragam tidak berbeda nyata dengan produk domestik. Uji Mikrobiologi (ALT) menujukkan bahwa seluruh produk memenuhi standar SNI.
\end{abstract}

Kata Kunci : Efektivitas CCDP-IFAD, Pengasapan ikan

\section{PENDAHULUAN}

1.1. Latar Belakang

Realita potensi sumber daya alam khususnya perikanan di Maluku Utara tidak berdampak baik bagi kehidupan perekonomian masyarakat nelayan. Tercatat jumlah masyarakat miskin di Maluku Utara mencapai 80.000 Jiwa. Untuk mengatasi hal tersebut diperlukan upaya membangun sumber daya manusianya dalam rangka meningkatkan perekonomian masyarakat. Optimalisasi potensi perlu dilakukan karena Maluku Utara adalah wilayah kepulauan dengan luas totalnya mencapai 140.255,32 $\mathrm{km}^{2}$. Dimana sebagian besar wilayah didominasi perairan laut, yaitu seluas $106.977,32 \mathrm{~km}^{2} 76,27 \%$ (BPS, 2015)

Terkait dengan upaya pemenuhan kebutuhan ekonomi, masyarakat nelayan pesisir Kota Ternate Maluku Utara didukung oleh para istri dalam upaya untuk pemenuhan kebutuhan ekonomi rumah tangga. Salah satu usaha pengolahan ikan yang digeluti adalah usaha pengasapan ikan. Hal ini dapat berdampak baik bagi perekonomian rumah tangga, namun upaya mencapai kemandirian ekonomi yang dilakukan oleh para nelayan tentu masih memerlukan adanya pemberdayaan yang tepat. Kebutuhan terhadap pemberdayaan ini sejalan dengan adanya program Coastal Comunnity Development Proyek (CCDP) yang diprakarsai oleh Internasional Fund for Agryculture Development (IFAD). Kota Ternate merupakan salah satu daerah yang ditetapkan mendapatkan program CCDP-IFAD. Proyek tersebut sebagai respon langsung terhadap kebijakan dan prakarsa Pemerintah Indonesia, khususnya Kementerian Kelautan dan Perikanan untuk pengentasan kemiskinan, penyerapan tenaga kerja, pertumbuhan ekonomi, dan pembangunan 
yang berkelanjutan. Adanya program ini diharapkan dapat membina nelayan untuk berdaya ekonomi. Untuk mendukung hal tersebut dilakukan penelitian mengenai efektivitas program Coastal Comunnity Development Project (CCDP-IFAD) terhadap industri Pengasapan ikan di Kota Ternate yang pada penelitian ini mengambil studi kasus kelompok industri pengasapan ikan Kelurahan Faudu Kecamatan Pulau Hiri.

\subsection{Tujuan Penulisan}

Tujuan penelitian ini adalah Menganalisis efektivitas program CCDP-IFAD terhadap peningkatan pendapatan, mutu produk ikan asap secara organoleptik dan mikrobiologi.

\section{METODE PENELITIAN}

Uji sensorik menggunakan lembar penilaian sensori (SNI 2725 : 2013). Uji ini meliputi rasa, aroma, tekstur, dan penampakan dengan menggunakan sebanyak 20 orang panelis. Analisis Data untuk mengetahui efektivitas program CCDP- IFAD terhadap peningkatan pendapatan nelayan menggunakan analisis statistik inferensi sampel berpasangan yaitu uji-t sampel berpasangan (paired samples $t$ test) untuk melihat adanya perbedaan tingkat pendapatan nelayan antara sebelum dan sesudah menerima program. Selanjutnya untuk uji organoleptik dilakukan analisis ragam untuk membandingkan apakah terdapat perbedaan nyata.

\subsection{Waktu dan tempat}

Penelitian dilaksanakan di Kelurahan Faudu, Kecamatan Pulau Hiri Kota Ternate, desember 2016 sampai dengan januari 2017. Uji organoleptik dilaksanakan di Laboratorium Pengolahan Program Studi THP Universitas Muhammadiyah Maluku Utara (UMMU) dan mutu mikrobiologi dilakukan di Laboratarium Balai Karantina Ikan kelas II Ternate.

\subsection{Bahan dan alat}

Bahan dan alat yang digunakan di antaranya lembar penilaian sensori (SNI 2725 : 2013) untuk organoleptik, kuisioner untuk wawancara tingkat pendapatan nelayan, dan untuk uji mikrobiologi menggunakan erlenmeyer, petridish, lemari, pengeram, pipet, Colony Counter, tabung reaksi, alat penghomogen (vortex), rak tabung reaksi, Bunsen, buffered peptone water (BPW), potatoes Dextrose Agar (PDA), sampel ikan asap Metode pengambilan data

Data tingkat pendapatan diperoleh dengan metode wawancara kepada 6 orang nelayan yang berasal dari tiga kelompok nelayan Ikan Asap di kelurahan Faudu. Data organoleptik dan mikrobiologi diperoleh dengan uji sensorik dan ATC terhadap tiga sampel dengan tiga kali ulangan, khusus untuk uji organoleptik melibatkan 20 orang panelis semi terlatih. Dua sampel diperoleh dari dua kelompok nelayan penerima program dan satu sampel lagi sebagai pembanding.

\subsection{Analisisi data}

Efektivitas

peningkatan

program terhadap pendapatan dianalisis menggunaka uji-t sampel berpasangan (paired samples $t$ test) untuk melihat adanya perbedaan tingkat pendapatan nelayan sebelum menerima sesudah menerima program. Rumus $t$ hitung pada inferensi sampel berpasangan adalah :

$$
t=\frac{\bar{d}}{s_{\bar{d}} / \sqrt{n}}
$$

Analisis mutu organoleptik menggunakan analisis variansi (anava) dengan rumus :

$$
\begin{aligned}
\mathrm{JKT} & =\sum_{i=1}^{k} \sum_{j=1}^{n_{i}} x_{i j}^{2}-\frac{T . .^{2}}{N} \\
\mathrm{JKP} & =\frac{\sum_{i=1}^{k} T_{i .}^{2}}{n_{i}}-\frac{T .^{2}}{N} \\
\mathrm{JKG} & =\mathbf{J K T}-\mathbf{J K P}
\end{aligned}
$$

Kriteria Penolakan $\mathrm{H}_{\mathbf{o}}$ : Kriteria untuk melakukan penolakan $H_{0}$ berdasarkan nilai statistik uji, yaitu Fhitung. Kriterianya $\mathrm{H}_{\mathrm{o}}$ ditolak jika Fhitung $>$ F table

\section{HASIL DAN PEMBAHASAN}

\subsection{Tingkat Pendapatan}

Nelayan pengolah ikan asap penerima program CCDP IFAD di kelurahan Faudu Kota Ternate memiliki potensi wirausaha melalui 
pengembangan home industry yang telah ada.

$3 \unrhd$ Beberapa potensi yang dapat dimanfaatkan di antaranya adalah daya serap pasar yang tinggi, masih terdapat ide inovasi dan diversifikasi lanjutan, dan ketersediaan bahan baku.
Program CCDP-IFAD diharapkan dapat memberikan manfaat kepada nelayan pengolah ikan asap berupa peningkatan pendapatan. Hasil penelitian menunjukkan tingkat pendapatan sebagaimana pada Tabel 1.

Tabel 1. Tingkat pendapatan sebelum dan sesudah menerima program

\begin{tabular}{crr}
\hline Anggota kelompok & \multicolumn{2}{c}{ Pendapatan } \\
\cline { 2 - 3 } Penerima program & Sebelum (Rp) & Sesudah (Rp) \\
\hline 1 & 800.000 & 800.000 \\
2 & 750.000 & 800.000 \\
3 & 1.000 .000 & 1.100 .000 \\
4 & 850.000 & 850.000 \\
5 & 600.000 & 650.000 \\
6 & 900.000 & 900.000 \\
\hline
\end{tabular}

Berdasarkan analisis statistik inferensi sampel berpasangan didapat bahwa Hipotesis $\mathrm{Ha}_{\mathrm{a}}$ (terjadi kenaikan yang signifikan) tertolak karena t-hitung lebih kecil dari $t$ tabel sehingga penarikan kesimpulan yaitu pengaruh adanya program tidak menunjukkan kenaikan pendapatan yang signifikan. Kesimpulan tersebut menuntut dirumuskannya strategi efektivitas program terhadap peningkatan pendapatan sebagai tujuan suatu pemberdayaan.
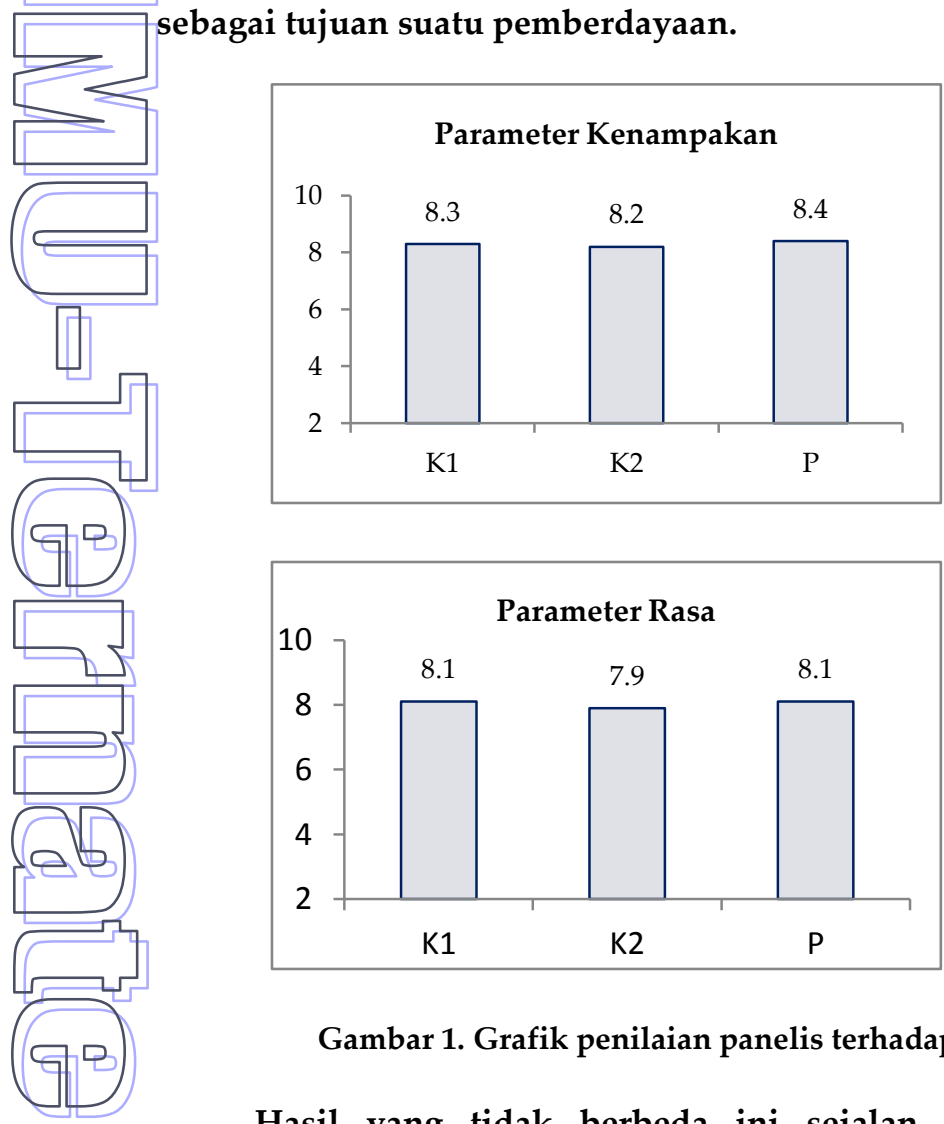

Gambar 1. Grafik penilaian panelis terhadap seluruh parameter organoleptik

Hasil yang tidak berbeda ini sejalan dengan analisis ragam pada semua parameter yang menunjukkan hasil yang tidak berbeda

\subsection{Uji Organoleptik}

Hasil penilaian panelis terhadap seluruh parameter organoleptik ikan asap berselisih sangat sedikit karena seluruh parameter hanya berkisar antara 7,8 sampai dengan 8,4 atau dibulatkan menjadi angka 8 . Grafik perbedaan penilaian panelis untuk parameter kenampakan dapat dilihat pada Gambar 1.
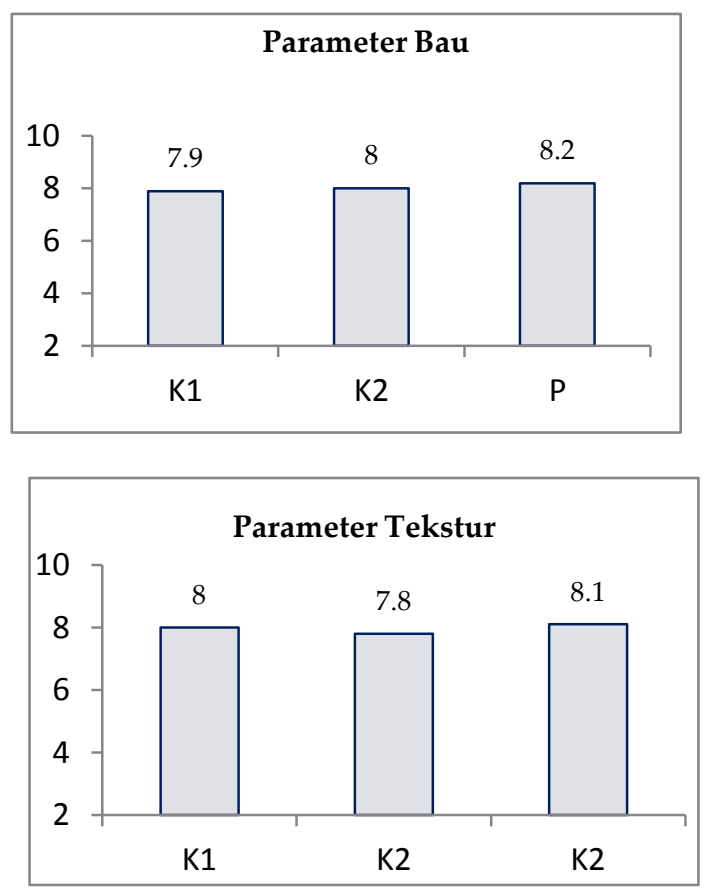

nyata dan secara umum keseluruhan produk telah memenuhi standar nasional Indonesia (SNI 2725 : 2013) Kenampakan yang bernilai 
tinggi dipengaruhi oleh banyaknya asap. Nastiti (2007) berpendapat bahwa dengan diasapi, ikan akan mendapat warna kuning emas sampai kecoklat-coklatan. Parameter aroma juga dipengaruhi oleh kandungan fenol dalam asap, yakni komponen fenol guailakol dan dimetoksi phenol (Swastawai et al, 2013)

Rasa yang enak dipengaruhi oleh banyaknya asap sama halnya dengan kenampakan. Martinez et al (2007) dalam Ghazali (2014), menyatakan bahwa senyawa fenol dan karbonil berperan untuk memberikan rasa pada ikan asap. Secara umum berdasarkan hasil - hasil yang didapat dari keseluruhan parameter maka sangat jelas terlihat bahwa adanya program CCDP-IFAD belum terlihat pengaruhnya terhadap industri pengasapan ikan khususnya dalam hal peningkatan mutu organoleptik produk.

\subsection{Uji Mikrobiologi (Angka Lempeng Total)}

Hasil uji ALT yang dilakukan di Laboratorium Stasiun Karantina Ikan Kelas I Ternate dengan perlakuan penyimpanan hari pertama, ke dua dan ke tiga didapat hasil sebagaimana terlihat pada Tabel 2.

Tabel 2. Laporan Hasil Uji ALT

\begin{tabular}{lccc}
\multicolumn{1}{c}{ Jenis Sampel } & Hari ke I & Hari ke II & Hari ke III \\
\hline \multicolumn{1}{c}{ I (Produk kelompok I) } & $8,1 \times 10^{5} \mathrm{CFU} / \mathrm{mg}$ & $3,5 \times 10^{8} \mathrm{CFU} / \mathrm{mg}$ & $6,3 \times 10^{11} \mathrm{CFU} / \mathrm{mg}$ \\
II (Produk kelompok II) & $5,5 \times 10^{5} \mathrm{CFU} / \mathrm{mg}$ & $3,1 \times 10^{9} \mathrm{CFU} / \mathrm{mg}$ & $9,2 \times 10^{13} \mathrm{CFU} / \mathrm{mg}$ \\
III (Produk domestik) & $3,7 \times 10^{5} \mathrm{CFU} / \mathrm{mg}$ & $5,1 \times 10^{8} \mathrm{CFU} / \mathrm{mg}$ & $3,7 \times 10^{11} \mathrm{CPU} / \mathrm{mg}$ \\
\hline
\end{tabular}

Hasil uji laboratorium yang ditampilkan pada tabel 1 secara umum terlihat bahwa dari hari ke hari terjadi peningkatan ALT yang siginifikan dari seluruh produk ikan asap dan berdasarkan Standar Nasional Indonesia (SNI) hanya pada hari pertama yang mendekati persyaratan mutu dan keamanan pangan yaitu 1 $x 10^{5} \mathrm{CFU} / \mathrm{mg}$. Ini menunjukkan tidak ada kelebihan dari produk yang dihasilkan oleh kelompok nelayan penerima program dibandingkan dengan produk non program dalam kaitannya dengan daya awet produk. Grafik peningkatan ALT pada hari pertama sampai dengan hari ke tiga dapat dilihat pada Gambar 2.

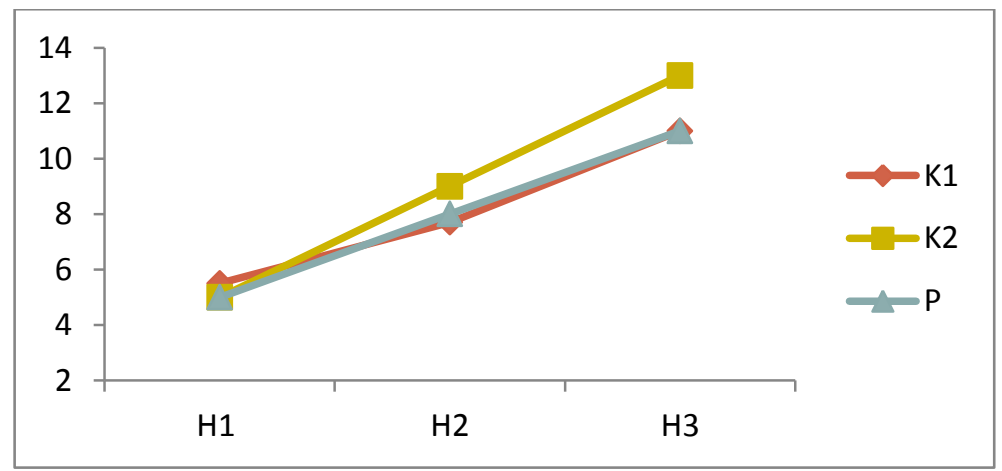

Keterangan : $\mathrm{H}=\mathrm{Hari}, \mathrm{K}=$ Kelompok

Gambar 2. Grafik Peningkatan ALT

Perlu adanya perbaikan cara pengolahan untuk meminimalisir lajunya peningkatan kandungan mikrobiologi yang dapat mempercepat pembusukan, baik dengan cara modernisasi pengolahan seperti pengemasan maupun penanganan yang sesuai dengan jaminan mutu.

Menurut Heruwati (2012) Kandungan protein ikan yang relatif tinggi, dengan kandungan air $10-60 \%$, cara pengolahan yang kurang saniter dan higienis, serta penyimpanan dalam keadaan tidak dilindungi/dikemas dengan baik pada kondisi tropik, mengakibatkan produk ikan olahan tradisional sangat rentan terhadap kerusakan mikrobiologis. Kerusakan mikrobiologis dapat menyebabkan pembusukan produk baik oleh bakteri atau jamur yang patogen maupun oleh racun yang dihasilkan. Penurunan nilai mutu kesegaran selain akan menurunkan nilai gizi 
atau nutriennya sebagai sumber pangan, juga akan menurunkan daya jual atau harga dari produk tersebut. Dengan demikian, nilai mutu kesegaran dari produk yang cepat busuk Dengan demikian aspek mikrobiologi sangat perlu diperhatikan Masalah pengetahuan nelayan menjadi faktor penyebab menurunnya mutu produk. Diperlukan adanya pendidikan yang dikemas dalam bentuk pelatihan yang berfokus pada perbaikan mutu. Ini menjadi salah satu faktor internal (kelemahan) yang perlu dibahas dalam perumusan strategi.

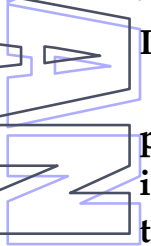

\section{KESIMPULAN}

Tingkat pendapatan mengalami sedikit peningkatan namun tidak merata dan hasil uji inferensi sampel berpasangan menunjukkan tidak ada peningkatan yang signifikan. Hasil uji organoleptik berupa uji sensorik menunjukkan hasil yang tidak berbeda antara produk nelayan program dengan produk nelayan non program. Analisis ragam juga menunjukkan hasil yang tidak berbeda nyata. Hasil Uji ALT menunjukkan bahwa berdasarkan SNI, hanya pada hari pertama yang mendekati persyaratan mutu dan keamanan pangan yaitu $1 \times 10^{5} \mathrm{CFU} / \mathrm{mg}$, sedangkan hari ke 2 dan hari ke 3 telah jauh melewati standar mutu dalam SNI.

\section{REKOMENDASI}

Penulis menyarankan agar dilakukan penelitian lanjutan mengenai Strategi yang tepat dalam mengimplementasikan proyek pemberdayaan ini sehingga dapat mencapai peningkatan pendapatan nelayan dan kualitas produk.

\section{DAFTAR PUSTAKA}

BPS Provinsi Maluku Utara (2015) Data Penduduk Miskin Maluku Utara. Diambil 2 Januari 2017, dari website BPS Maluku Utara. http://malut.bps.go.id/linkTableDinamis/view/id/73

Gazhali, R. R., Swastawati, F. dan Romadhon. (2014). Analisa Tingkat Keamanan Ikan Manyung (Arius thalassinus) Asap yang Diolah dengan Metode Pengasapan Berbeda. Jurnal Pengolahan dan Bioteknologi Hasil Perikanan, vol. 3, no. 4, hal. 32-33

Handayani, D., Laila, F. Margareth, dan Arifan, F. (2014). Meningkatkan Pendapatan Nelayan dan Masyarakat Pengolah Ikan Panggang dengan Memanfaatkan Asap Cair. Jurnal Metana, vol. 10, no. 2, hal. 30

Heruwati, E.S. (2012). Pengolahan Ikan Secara Tradisional, Prospek dan Peluang Pengembangan. Jurnal Litbang Pertanian, vol. 2, no. 3, hal. 12-13.

7 Nastiti, D. (2006). Kajian Mutu Produk Ikan Manyung (Arius thalasinnus) Panggang di Kota Semarang, Semarang : Tesis. Program Pascasarjana Magister Sumberdaya Pantai UNDIP.

Swastawati, F. (2011). Studi Kelayakan dan Efesiensi Usaha Pengasapan Ikan dengan Asap Cair Limbah Pertanian. Jurnal Dinamika Ekonomi Pembangunan, vol. 1, no. 2, hal. 20

Tanggelangi, R. Arkwright, D. (2012). Strategi Program Pemberdayaan Masyarakat di Desa Koloray Kecamatan Morotai Selatan. Jurnal Uniera, vol. 1, no. 2, hal. 2. 